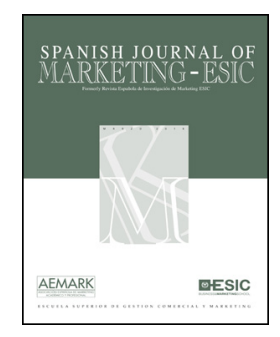

\title{
ARTICLE
}

\section{Determinants of intention to use the mobile banking apps: An extension of the classic TAM model}

\author{
F. Muñoz-Leivaa, ${ }^{a, *}$ S. Climent-Climent ${ }^{\mathrm{b}}$, F. Liébana-Cabanillas ${ }^{\mathrm{a}}$ \\ a Department of Marketing and Market Research, University of Granada, Granada, Spain \\ ${ }^{\mathrm{b}}$ Faculty of Business and Business Administration, University of Granada, Granada, Spain
}

Received 6 May 2016; accepted 2 December 2016

Available online 7 January 2017

\section{KEYWORDS}

Mobile banking;

Mobile apps;

Trust;

Risk;

Social image;

TAM

\section{PALABRAS CLAVE}

\section{Banca para móviles;}

aplicaciones para

móviles;

confianza;

riesgo;

imagen social;

TAM

\begin{abstract}
For financial institutions mobile banking has represented a breakthrough in terms of remote banking services. However, many customers remain uncertain due to its security. This study develops a technology acceptance model that integrates the innovation diffusion theory, perceived risk and trust in the classic TAM model in order to shed light on what factors determine user acceptance of mobile banking applications. The participants had to examine a mobile application of the largest European bank. In the proposed model, an approach to external influences was included, theoretically and originally stated by Davis et al. (1989). The proposed model was empirically tested using data collected from an online survey applying structural equation modeling (SEM). The results obtained in this study demonstrate how attitude determine mainly the intended use of mobile apps, discarding usefulness and risk as factors that directly improve its use. Finally, the study shows the main management implications and identifies certain strategies to reinforce this new business in the context of new technological advances.
\end{abstract}

๑ 2016 ESIC \& AEMARK. Published by Elsevier España, S.L.U. This is an open access article under the CC BY-NC-ND license (http://creativecommons.org/licenses/by-nc-nd/4.0/).

Determinantes de la intención de uso de las aplicaciones de banca para móviles: una extensión del modelo TAM clásico

Resumen Para las entidades financieras la banca para móviles ha representado una innovación en términos de servicios de banca remota. Sin embargo, muchos clientes siguen considerando incierta su seguridad. Este estudio desarrolla un modelo de aceptación tecnológica que integra, en el modelo TAM clásico, la teoría de la difusión de la innovación, el riesgo percibido y la confianza, a fin de clarificar qué factores determinan la aceptación de las aplicaciones de banca

\footnotetext{
* Corresponding author at: Department of Marketing and Market Research, UGR, Campus Cartuja, Granada, Spain.

E-mail address: franml@ugr.es (F. Muñoz-Leiva).
} 
para móviles por parte del usuario. Los participantes tuvieron que examinar una aplicación para móviles perteneciente al mayor banco europeo. En el modelo propuesto, se incluyó una aproximación hacia las influencias externas, que fue establecida de manera teórica y original por parte de Davis et al. (1989). El modelo propuesto se testó empíricamente utilizando la información recolectada mediante una encuesta online, aplicando el modelo de ecuaciones estructurales (SEM). Los resultados obtenidos en el estudio demuestran el modo en que la actitud determina principalmente el uso previsto de las aplicaciones para móvil, descartando la utilidad y el riesgo como factores que mejoran directamente su uso. Por último, el estudio muestra las principales implicaciones para la gestión, e identifica ciertas estrategias de refuerzo de este nuevo negocio en el contexto de los nuevos avances tecnológicos.

(c) 2016 ESIC \& AEMARK. Publicado por Elsevier España, S.L.U. Este es un artículo Open Access bajo la licencia CC BY-NC-ND (http://creativecommons.org/licenses/by-nc-nd/4.0/).

\section{Introduction mobile banking \& mobile commerce}

\section{Online banking services}

Banks are considered highly dynamic business entities that, joined in a global network, offer better conditions to those clients who decide to use online banking services (MuñozLeiva, Sánchez-Fernández, \& Luque-Martínez, 2010). This sector, as in many others, converts the Internet and mobile applications or apps into the most effective channel for offering banking products and services to clients. As a consequence, we are witnessing an increasingly competitive banking sector with increasingly demanding clients (Shaikh \& Karjaluoto, 2015).

Since electronic banking first appeared, Web apps have gained rapid popularity due to the advantages they offer banking entities in terms of comfort and ease when performing client transactions, increasing market coverage and service quality. In contrast to traditional banking activities, online banking provides more features and functionalities at a lower cost (Laukkanen, 2007).

Online banking and mobile apps of financial entities allow users to, among other advantages, access their accounts from any location and at any time. Such accessibility represents an advantage over traditional banks. Despite all of this, it is important to highlight that the number of clients that operate through online banking has not increased as much as it was expected. Aspects such as the lack of differentiation between banks, lack of trust in the system, impersonal treatment or lack of security have caused reluctance from many customers to use such tools (Muñoz-Leiva et al., 2010).

According to a recent study by Price Waterhouse ${ }^{1}$ conducted in 2013 involving 157 managers for technology and systems for financial institutions in 14 major markets in America, Europe and the Asia-Pacific, the weight of digital channels in retail banking will grow significantly in the coming years. The number of mobile banking (or $\mathrm{m}$-banking) users will increase by $64 \%$ until 2016; and those who make

\footnotetext{
1 http://www.pwc.es/es/publicaciones/financiero-seguros/ encuesta-mundial-banca-digital.jhtml.
}

Table 1 Previous studies approaching the rate of adoption of mobile banking apps.

\begin{tabular}{ll}
\hline Constructs & Authors \\
\hline $\begin{array}{l}\text { Performance expectancy, effort } \\
\text { expectancy, facilitating }\end{array}$ & Hew et al. (2015) \\
$\begin{array}{l}\text { conditions, hedonic motivation } \\
\text { Social identification, stickiness }\end{array}$ & Hsu and Lin (2016) \\
Perceived compatibility, attitude & Harrison (2015) \\
\hline
\end{tabular}

purchases through social networks and use online banking will also significantly increases, $56 \%$ and $37 \%$ respectively. This situation will be detrimental to other traditional channels such as bank branches and telephone banking, whose users will fall by $25 \%$ and $13 \%$ respectively. However, they will not disappear and they will continue to have an important role focused on the most complex banking.

In light of the above, the banking sector has not been immune to the development of mobile apps. In this context, Lee, McGoldrick, Keeling, and Doherty (2003) stated or mbanking apps to be an innovation that could become one of m-commerce's value-added apps. Zhou, Lu, and Wang (2010) defined m-banking as the use of mobile devices such as cell phones and personal digital assistants (PDAs) to access banking networks via the wireless application protocol (WAP). And finally, Luo, Li, Zhang, and Shim (2010) describe it as an innovative method for accessing banking services via a channel whereby the customer interacts with a bank via a mobile device. Upon considering these definitions, we propose to define mobile banking as a remote service (via mobile phone, PDAs, tablets, etc.) offered by financial entities to meet the needs of their customers.

Regarding researches exploring mobile banking apps (for smartphones) and their rate of adoption, it is worth noting that this study only found a few previous research studies approaching the most significant antecedents regarding users' intention to use of said apps (see Table 1). Hew, Lee, Ooi, and Wei (2015) suggested that apps which are easy to use would attract consumers to use them; furthermore, the significant and positive association between effort expectancy and ease of use had also been confirmed, and finally consumers' perception on the usefulness of apps 
would directly influenced by the user-friendliness of the apps. On one hand, Harrison (2015) suggested that perceived compatibility had the strongest effect on behavioral intention; and on the other hand, credibility, performance expectancy, effort expectancy, and social influence, ordered by their effect size, significantly influence attitude toward mobile banking, which in turn influenced behavioral intention. Finally, Hsu and Lin (2016) suggested that stickiness and social identification significantly influence a user's intention to make in-app purchases.

Furthermore, despite recent and different extensions of the Davis et al.'s (1989) Technology Acceptance Model (TAM), just a few studies have focused on the factors that influence the acceptance of these mobile apps from a holistic approach integrating several principles associated with the theory of trust, risk and social image (e.g. Liébana Cabanillas, 2012; Liébana-Cabanillas, Sánchez-Fernández, \& Muñoz-Leiva, 2014a, 2014b) or social influences or subjective norms (Bashir \& Madhavaiah, 2015; Sellitto, 2015; Slade, Dwivedi, Piercy, \& Williams, 2015).

In order to fill this gap, the present paper proposes a conceptual model that integrates the main determining variables regarding user behavior related to the adoption of an innovative technology in online banking. The article, using the TAM model as a framework and its subsequent extensions, aims to model the m-banking user behavior through the relationships that exist between different variables such as: social image, usefulness, user-friendliness, trust, intention to adopt the technology, etc. These relationships between variables will be explained in detail in next section.

With regard to the structure, this article consists of these sections: the next section refers to the conceptual framework that will support the research hypotheses; the subsequent sections correspond to the empirical research; and the final section extracts the main findings, and contributions and limitations arising from the research.

\section{Scientific literature review, research hypothesis}

In the next paragraphs, the theoretical framework of the proposed research will be summarized, specified in the context of a behavioral model. The literature review and the use of the Technology Acceptance Model (TAM) as a starting point have led to the development of a behavioral model that explains the process of adoption of $\mathrm{m}$-banking apps among potential users.

\section{Hypotheses for research related to the TAM}

In order to analyze the user behavior regarding the adoption of innovative technology, several behavioral decision theories and intentional models have been developed by scientific literature over the last four decades. According to the aim of this study, and due to the relevance regarding the explanation of online consumer behavior, we have used these attitudinal models and theories based on Social Psychology, such as the Technology Acceptance Model, or TAM (Davis, Bagozzi, \& Warshaw, 1989). The TAM model, was designed based on the Theory of Reasoned Action, or TRA
(Fishbein \& Ajzen, 1975; Ajzen \& Fishbein, 1980) with the aim of making predictions on acceptance and use of new information technologies and systems, by identifying the features that drive success for company's information systems and their adaptability to work-related needs (Davis et al., 1989).

These attitudinal models are based on the benefits provided by information systems, eliminating the negative traits of its use. The models are based on describing the characteristics of the information processes that lead to intentions to either accept or reject a technological innovation.

The TAM has been regarded as the most robust, parsimonious and influential model in innovations acceptance behavior (Davis et al., 1989; Pavlou, 2003), and therefore, we consider this theoretical model as a base for the purpose of the present study. The TAM model states attitude toward use of new technology as a construct explained by two perceived variables: usefulness and ease of use.

Perceived ease of use is defined as: the degree to which a person believes that using a particular system would be free of effort within an organizational context" (Davis et al., 1989: 985). The approximation to this construct is based on measures to determine how systems allow you to perform tasks faster, increase productivity, performance and work efficiency. The effect of perceived ease of use on attitude has been shown in various studies applied to different contexts (Chau \& Lai, 2003; Hernández, 2010). It was also found that this construct has a positive impact on attitude toward mobile social network games (Park, Baek, Ohm, \& Chang, 2014); and according to $\mathrm{Ha}$, Yoon, and Choi (2007) on attitude toward mobile games. Considering these fundamentals, we have formulated the following hypothesis:

H1. The ease of use of the proposed m-banking apps has a positive impact on the users' attitude toward it.

In addition, it was found that ease of use has a positive impact on usefulness of virtual communities (Hsu \& Lu, 2007), in the electronic banking sector (Aldás, Lassala, Ruiz, \& Sanz, 2011; Muñoz-Leiva et al., 2012; Liébana-Cabanillas, Muñoz-Leiva, \& Rejón-Guardia, 2013), or in the case of mobile games applications (Ha et al., 2007). Thus:

H2. The ease of use of the proposed m-banking apps has a positive impact on its perceived usefulness.

Since the original TAM, perceived usefulness has been applied to a wide range of ITs to measure innovation performance for job, life and study (Liu \& Li, 2011). According to Davis (1989), perceived usefulness can be defined as: "the degree to which a person believes that using a specific system will increase his or her job performance"' (p. 985). On several occasions, perceived usefulness has also been seen as a perceived relative advantage; for this reason, Rogers (2003) considers a similar construct named "relative advantage" defined as "the way it is perceived as being 'better' than its predecessor"'.

In our study, this variable is relevant since mobile applications of banks are considered innovative within online banking, and the usefulness provided consumers is closely related to the advantages that it offers. 
Several studies have demonstrated the direct relationship between perceived usefulness and attitude (Muñoz et al., 2012; Aboelmaged \& Gebba, 2013; Krishanan, Khin, Teng, \& Chinna, 2016). Although also with the intention to use (Gu, Lee, \& Suh, 2009; Jeong \& Yoon, 2013; Ko, Kim, \& Lee, 2009; Kulviwat et al., 2007; Liu \& Li, 2011; Zhang \& Mao, 2008). In connection with the above, we state the following hypotheses:

H3. Perceived usefulness has a positive effect on users' attitude toward the proposed m-banking apps.

Studies related to the effects of perceived usefulness in the field of new technologies present different results. Some studies support the significant and positive effect of this construct on intention to using (Pham \& Ho, 2015), while others do not show significant results for this relationship ( $\mathrm{Li}$, Liu, \& Heikkilä, 2014).

In this sense, we consider it even more important to contrast this hypothesis since the use of $\mathrm{m}$-banking apps is still considered an innovation within existing payment systems and the usefulness it provides to the consumer will be closely related to its adoption.

Therefore, we propose the following hypothesis:

H4. Perceived usefulness has a positive effect on the intention of use of the proposed $\mathrm{m}$-banking apps.

Furthermore, both the TRA and TAM have shown that attitude is an essential antecedent to intentions when it comes to developing a particular behavior. According to Fishbein and Ajzen (1975), attitude can be defined as a multidimensional construct, consisting of three dimensions: cognitive (experience, beliefs and opinions), affective or emotional (feelings, emotions and subjective evaluations) and a conative or behavioral dimension (intention to purchase, respect to purchase and response to rejection).

The main criticism received by this concept revolves around the fact that most consumers respond to the emotional component, without giving much importance to the rest, which complicates the measurement of consumer attitudes. It is for this reason that the multidimensional concept is abandoned in favor of a one-dimensional concept, so that the cognitive and conative compounds are relocated outside the attitude concept; the first as beliefs or knowledge and the second as intention (Alcántara, 2012).

According to our research, it is expected that attitude facilitates transactions and serve to reduce barriers toward the adoption of innovation (Pavlou, 2002; LiébanaCabanillas et al., 2014a). It is also expected to favor intended use of the proposed mobile application (Saghafi, Moghaddam, \& Aslani, 2016). According to the above, we have proposed the following hypothesis:

H5. Users' attitude toward using the proposed m-banking apps has a positive effect on their intention of using it.

Shaikh and Karjaluoto (2015) performed a systematic review of literature on $\mathrm{m}$-banking adoption published from January 2005 to March 2014, concluding that the TAM model and its adaptations is the most employed in published works. In this vein, we have focused our study on the original TAM model considered the most relevant, although we have also included the following external influences: social image, trust and perceived risk.

\section{Extension of the TAM: social image, trust and perceived risk}

According to Goffman (1967) social image is a desired social value that each person creates through interaction with others. In our research, social image is important because innovation can provide users with a sense of uncertainty about the consequences of consumption, and therefore, users may choose to seek advice from others for opinions and personal experiences.

Social image is associated with factors such as respect, honor, status, reputation, credibility, competence, social connection, loyalty, trust, feeling proud/ashamed, etc. (Bao et al., 2003). Lin and Bhattacherjee (2010) defined social image as the "extent to which users may derive respect and admiration from peers in their social network as a result of their IT usage."' In order to keep a distinct social image, the presence of other people surrounding the user to reinforce or reject said image becomes necessary (White et al., 2004). Therefore, social image is capable of influencing the ease of use of advanced mobile services (López-Nicolás, MolinaCastillo, \& Bouwman, 2008). As a consequence to the above mentioned, we propose the following hypotheses:

H6. Social image has a positive effect on the ease of use of m-banking apps.

Furthermore, social image is capable of inducing the usefulness of mobile data services and $3 G$ adoption, as it is founded in previous studies (Hong \& Tam, 2006; Chong, Ooi, Lin, \& Bao, 2012; respectively). Thus, we propose the next:

H7. Social image has a positive effect on the usefulness of m-banking apps.

In this regard, social image is also expected of being capable of directly influencing the attitude toward mobile services (Grandón, Nasco, \& Mykytyn, 2011; Liang, 2016; Schierz, Schilke, \& Wirtz, 2010). Therefore:

H8. Social image has a positive effect on attitudes toward m-banking apps.

Trust has been widely studied and its definitions are numerous. Gefen, Karahanna, and Straub (2003b) defined trust as "the expectation that other individuals or companies with whom one interacts will not take undue advantage of a dependence upon them' (p. 308). Traditionally, trust has been formed by two basic components: a cognitive component that defines trust as "the belief that the other party's word or promise is reliable and the party will fulfill its obligations in an exchange relationship" (Dwyer, Schurr, \& Oh, 1987: 18; Schurr \& Ozanne, 1985: 940); and a behavioral component that is defined as the willingness or desire to follow a particular pattern of behavior, which determines the success rate of acceptance of the innovation (LiébanaCabanillas et al., 2014b: 154). 
The generation of trust has been considered a decisive factor in stimulating purchases over the Internet (Gefen, Rao, \& Tractinsky, 2003a; Gefen et al., 2003b). The reason for such importance lies in the fact that, in the absence of any practical guarantee, the consumer cannot be certain that the seller will not resort to undesirable, opportunistic behavior, such as violation of privacy, unauthorized use of credit card information, unequitative pricing or access to unauthorized transactions (Reichheld \& Schefter, 2000). The consumer will therefore be affected by a sense of insecurity and concern about the privacy and control of his or her personal information. Generation of trust can compensate this concern about security and privacy (Rifon, LaRose, $\&$ Choi, 2005) and so companies with electronic commerce seek feasible, efficient means of increasing perceived trust and, thereby, their traffic and sales (e.g., Stewart, 2003). Therefore, we propose a relationship between trust and risk, being the second one a consequence of the first one (Harris, Brookshire, \& Chin, 2016; Slade et al., 2015). Therefore, we propose the following hypothesis:

H9. Perceived trust in the proposed $m$-banking app has a negative effect on users' perceived risk toward it.

In our research, trust is proposed as an antecedent to ease of use, based on the idea that trust reduces the need to understand, control and monitor the situation, facilitating the use of the tool for the user without much effort. In the context of the Internet, authors like Pavlou (2002, 2003) and Bounagui and Nel (2009) have identified a positive relationship between trust and ease of use. Thus:

H10. Perceived trust in the proposed m-banking app has a positive effect on the ease of use of it.

Other studies have also shown a positive relationship between trust and attitude (Agag and El-Masry, 2016; Chauhan, 2015), as well as between trust and risk (Park \& Tussyadiah, 2016; Pavlou, 2003). Therefore:

H11. Perceived trust in the proposed m-banking app has a positive effect on users' attitude toward it.

Lastly, perceived risk was initially approached by Bauer (1960) through the analysis of two factors: uncertainty (lack of consumer knowledge regarding the possible outcome of a certain transaction) and the possible negative consequences derived from the purchasing procedure (transaction). The same author also stated later on that any given user behavior is associated with a particular risk since the consequences of said behavior cannot be properly assessed beforehand (Bauer, 1967). Also, Gerrard and Cunningham (2003) approached the same concept as "the uncertainty about what the innovation gives"' (p. 19); and Gupta and Kim (2010) as "a customer's perception of the uncertainty and adverse consequences of conducting transactions with a vendor' (p. 19). Perceived risk constitutes a multidimensional construct built from several different factors explaining the overall risk associated with the adoption of a certain innovation, purchase or service (Featherman \& Pavlou, 2003; Aldás et al., 2011), as we have defined in this research.
Various studies have revealed that perceived risk negatively influences attitude (Zimmer et al., 2010) and, therefore, intention of adopting e-commerce (Crespo \& del Bosque, 2010; Herrero \& San Martín, 2012) and remote or mobile payment systems (Liébana-Cabanillas et al., 2014a; Liébana-Cabanillas, Muñoz-Leiva, \& Sánchez-Fernández, 2017; Slade et al., 2015). In our research, perceived risk is crucial since it is considered an antecedent of intention to use. Therefore, we propose this research hypothesis:

H12. The perceived risk of the proposed m-banking apps has a negative effect on users' intention of using it.

Fig. 1 summarizes our proposed model.

\section{Methodological aspects}

\section{Sampling procedure}

As for the methodological aspects of research applied to carry out the experience, a web study was applied that consisted of the viewing of an explanatory video of the mobile application of Banco Santander (Fig. 2), which described the tool's operation, features and advantages. At the end of the video, we proceeded to gather answers from an online questionnaire designed in Google Docs sent to a random selection of subjects who either had used a mobile banking app or were familiar with it. The invitation to the online survey was conducted by email due to its high social impact and therefore faster response.

According to the last report published by Price Waterhouse Coopers (2013) on "Global insights and actions for Banks in the digital age", the number of mobile banking users will increase by $64 \%$ by 2016 . In the same line, the data gathered by Tecnocom Report (2012) show that Spain's user base increased by 113\% between 2011 and 2012, reaching almost 6 million users. These data collected is similar to the information found in the Tecnocom Report (2012), which points out that $15.1 \%$ of Spanish adults use either a mobile version or a mobile app of their bank's website. Concerning their environment, according to the ING International Survey on Financial Empowerment in the Digital Era (2013), the Spanish population has the highest use rate of mobile banking among Europeans, ranking only behind Turkey. This is the reason why Banco Santander was selected for this study, since it is the largest Spanish bank in terms of stock capitalization according to the British magazine The Banker (www.thebanker.com) and it occupies the 14th position in the global ranking.

Fieldwork began on August 15, 2014, and ended on August 31,2014 , and participation was entirely voluntary. The final sample was composed of 103 regular users of electronic banking, and obtains a sampling error of $9.66 \%$ in the estimation of a proportion, under the assumptions of simple random sampling. The final sample was integrated by 53 male $(51.5 \%)$ and 50 female (48.5\%) participants, with 55 individuals aged in the $18-34$ range $(53.4 \%)$ and $48(46.6 \%)$ aged 35 or older.

Table 2 lists the specifications of the study. 


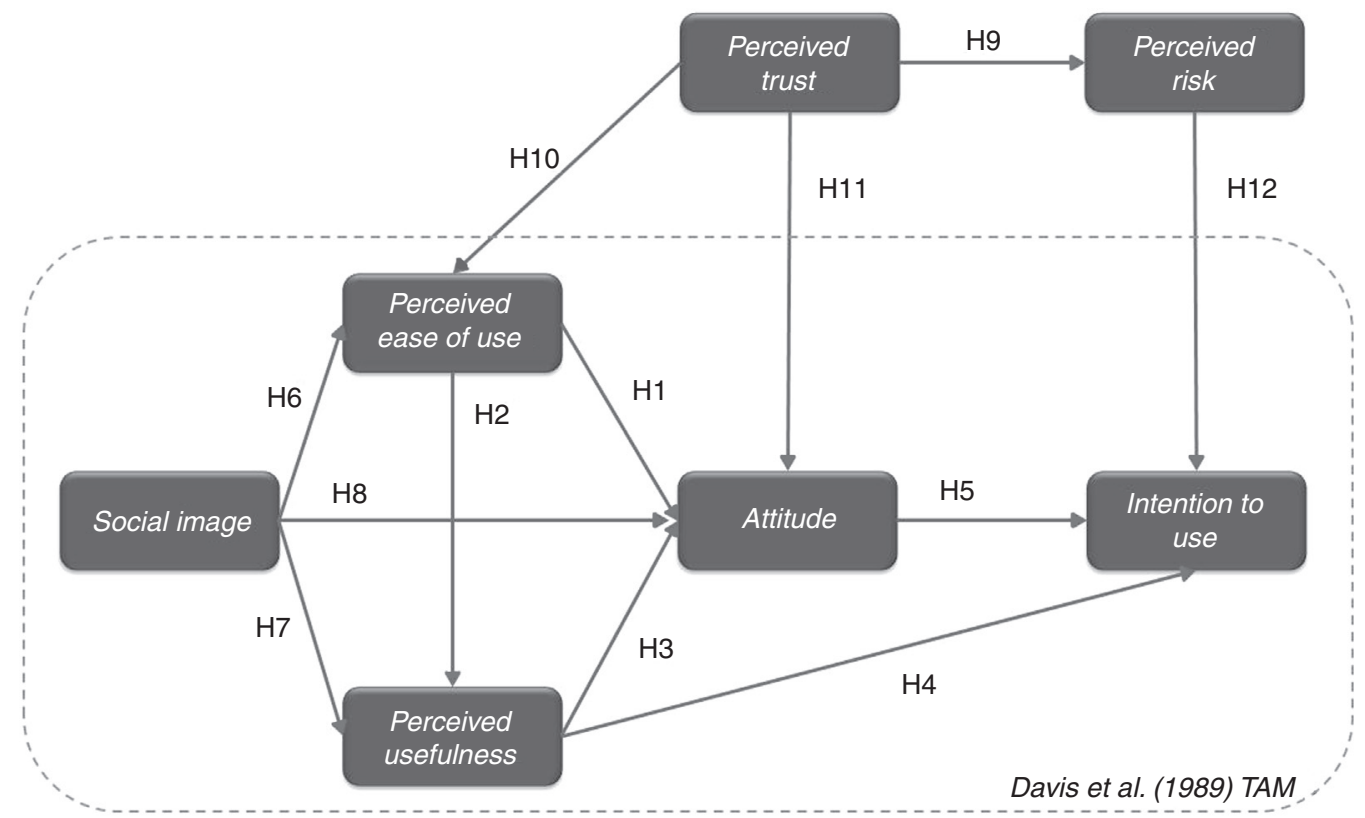

Figure 1 The m-banking adoption model.
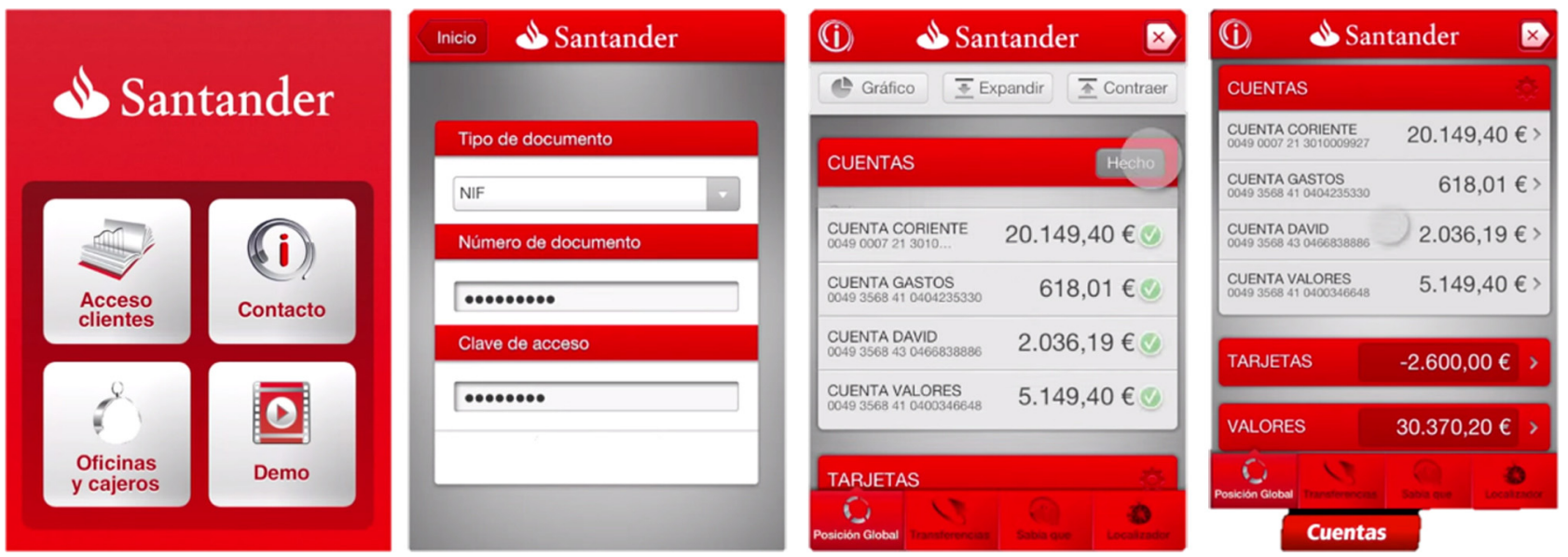

Figure 2 Video images shown to subjects.

Source: Youtube (2012).

Table 2 Technical overview.

\begin{tabular}{ll}
\hline $\begin{array}{l}\text { Fieldwork } \\
\text { Population }\end{array}$ & $\begin{array}{l}\text { 15-31 August 2014 } \\
\text { Potential mobile banking } \\
\text { application users }\end{array}$ \\
$\begin{array}{l}\text { Population size } \\
\text { Sample size }\end{array}$ & $\begin{array}{l}\text { 5.9 billion online banking users } \\
\text { Convenience sampling method. } \\
\text { Contact by } \\
\text { Online } \\
\text { Type of survey }\end{array}$ \\
$\begin{array}{l}\text { Average interview } \\
\text { duration }\end{array}$ & $\begin{array}{l}\text { Sample size (surveys } 18 \mathrm{~s} \\
\text { started) }\end{array}$ \\
$\begin{array}{l}\text { Sampling error } \\
\text { a }\end{array}$ & $\begin{array}{l}9.66 \% \text {, estimating } p=q=0.5 \text { and } \\
\text { trust level of } 95 \%\end{array}$ \\
\hline
\end{tabular}

a Under the assumptions of simple random sampling.

\section{Surveys and measurement scales used}

The measurement scales used in the online survey were adapted from previous research (Appendix A). Social image was measured based on adaptations of the scales used by Venkatesh and Bala (2008), Venkatesh and Davis (2000) and Moore and Benbasat (1991). The ease of use scale was adapted by studies from Venkatesh and Bala (2008).

The final questionnaire consisted of 22 items. The questions were divided into three sections: 1) questions relating to evaluation; 2 ) questions relating to the subject of the investigation; and 3) questions relating to sociodemographic data. All these questions correspond to the conceptual theoretical model defined above, collecting the hypothesized relationships. The majority of items (18) presented a graduation according to the Likert-type scales: from 1 (strongly disagree) to 7 (strongly agree), an item from 
Table 3 Convergent validity and internal consistency analysis.

\begin{tabular}{|c|c|c|c|c|c|c|}
\hline \multicolumn{3}{|c|}{ Relationships between constructs } & \multirow{2}{*}{$\begin{array}{l}\text { Standard coefficient } \\
0.86\end{array}$} & \multirow[t]{2}{*}{ Cronbach's $\alpha$} & \multirow[t]{2}{*}{ CR } & \multirow[t]{2}{*}{ AVE } \\
\hline \multirow{4}{*}{$\begin{array}{l}\text { Perceived ease } \\
\text { of use }\end{array}$} & $\rightarrow$ & PEOU1 & & & & \\
\hline & $\rightarrow$ & PEOU2 & 0.78 & \multirow{3}{*}{0.926} & \multirow{3}{*}{0.93} & \multirow{3}{*}{0.76} \\
\hline & $\rightarrow$ & PEOU3 & 0.91 & & & \\
\hline & $\rightarrow$ & PEOU4 & 0.94 & & & \\
\hline \multirow{3}{*}{$\begin{array}{l}\text { Perceived } \\
\text { usefulness }\end{array}$} & $\rightarrow$ & PU1 & 0.95 & \multirow{3}{*}{0.917} & \multirow{3}{*}{0.92} & \multirow{3}{*}{0.80} \\
\hline & $\rightarrow$ & PU2 & 0.90 & & & \\
\hline & $\rightarrow$ & PU3 & 0.83 & & & \\
\hline \multirow{3}{*}{ Attitude to use } & $\rightarrow$ & ATT1 & 0.84 & \multirow{3}{*}{0.926} & \multirow{3}{*}{0.93} & \multirow{3}{*}{0.81} \\
\hline & $\rightarrow$ & ATT2 & 0.93 & & & \\
\hline & $\rightarrow$ & ATT3 & 0.93 & & & \\
\hline \multirow{3}{*}{ Social image } & $\rightarrow$ & $\mathrm{SI} 1$ & 0.93 & \multirow{3}{*}{0.939} & \multirow{3}{*}{0.94} & \multirow{3}{*}{0.84} \\
\hline & $\rightarrow$ & $\mathrm{SI} 2$ & 0.97 & & & \\
\hline & $\rightarrow$ & $\mathrm{SI} 3$ & 0.86 & & & \\
\hline \multirow{3}{*}{ Trust } & $\rightarrow$ & TRU1 & 0.89 & \multirow{3}{*}{0.928} & \multirow{3}{*}{0.93} & \multirow{3}{*}{0.82} \\
\hline & $\rightarrow$ & TRU2 & 0.95 & & & \\
\hline & $\rightarrow$ & TRU3 & 0.88 & & & \\
\hline \multirow{3}{*}{ Perceived risk } & $\rightarrow$ & PR1 & 0.89 & \multirow{3}{*}{0.912} & \multirow{3}{*}{0.91} & \multirow{3}{*}{0.78} \\
\hline & $\rightarrow$ & PR2 & 0.92 & & & \\
\hline & $\rightarrow$ & PR3 & 0.83 & & & \\
\hline \multirow{2}{*}{ Intention to use } & $\rightarrow$ & IU1 & 0.90 & \multirow{2}{*}{0.943} & \multirow{2}{*}{0.81} & \multirow{2}{*}{0.79} \\
\hline & $\rightarrow$ & IU2 & 0.89 & & & \\
\hline
\end{tabular}

1 (like it) to 7 (don't like it), another item from 1 (boring) to 7 (interesting); and one last item from 1 (absurd) to 7 (interesting).

The data collected for these measurement scales were subsequently analyzed by the AMOS 18 software.

\section{Research findings}

\section{Reliability and validity analysis}

First, to measure the reliability of the scales, the Cronbach's alpha indicator was used, considering the reference value 0.6 (Malhotra, 1997), or to be more restrictive, 0.7 (Nunnally, 1978).

In order to contrast the convergent and divergent validity of the scales, a confirmatory factor analysis (CFA) was subsequently performed. This analysis included all scales of measurement to extract the variance extracted from each one of them, as well as correlations between constructs and their confidence intervals. In particular, the maximumlikelihood estimation (MLE) method was used under the resampling technique (bootstrap) with 500 replicates, since the traditional MLE is very sensitive to sample size and requires that the variables follow a multi-normal distribution (Finney \& DiStefano, 1996), a fact that did not occur in our sample. In the bootstrap technique, the $p$-value corrected by Bollen-Stine and the standard error corrections of the constructs were used (West, Finch, \& Curran, 1995).

Convergent validity was assessed by the factor loadings of the indicators. It was found that the coefficients were significantly different from zero, and also, that the loads between the latent and observed variables were high in all cases $(\lambda>0.7)$. Therefore, we can state that the latent variables adequately explained the observed variables (Del Barrio \& Luque, 2012).

Regarding discriminant validity, it was found that the variances were significantly different from zero and also, that the correlation between each pair of scales did not exceed 0.9 (Hair, Anderson, Tatham, \& William, 1995) or, better yet, 0.8 (Flavián, Guinalíu, \& Gurrea, 2004).

Again, the reliability of the scales can be evaluated based on a series of indicators extracted from confirmatory analysis. Indeed, the composite reliability of the construct and the analysis of the variance extracted (AVE) exceeded the threshold used as reference, 0.7 and 0.5 , respectively, as well as other indicators of overall fit for the measurement model (Table 3).

\section{Evaluation of the discriminant validity between latent constructs}

Having assessed the quality of all proposed measurement scales, we verified if together all latent constructs have discriminant validity, i.e. that the constructs that make up the model are significantly different, since the discriminant validity between the dimensions of a same scale does not guarantee that discriminant validity will have different latent constructs (Luque, 1997).

Discriminant validity occurs when (Muñoz, 2008): 1) the value 1 is not situated in the confidence interval at $95 \%$ 
for the correlations between the constructs, taken in pairs (Anderson \& Gerbing, 1988), 2) the correlation between different pairs of latent variables is less than 0.9 (Hair et al., 1995) and 3) the shared variance between a construct and its measures (extracted variance) exceeds the shared variance between the construct and other constructs of the model (Fornell \& Larcker, 1981).

In the case of our study, it was found that the correlations between constructs (extracted from the CFA) were not too high, no construct had the value 1 in its confidence intervals and the correlations between indicators were below the root of the extracted variance of each of the constructs taken in pairs of two, which allowed us to conclude that overall there was discriminant validity between the different latent constructs considered.

\section{Discussion of findings: testing the hypotheses and the structural model}

After analyzing the reliability and validity of the measurement scales, we proceeded to test the hypotheses derived from previously conducted research, checking previously that the adaptation of the proposed structural equation model (SEM) was reasonably good according to the recommended levels: RMSEA $<0.08, \mathrm{CFI}$ and NFI > 0.85 (Bollen, 1990; Lai \& Li, 2005) (Table 4).

To evaluate the SEM, the statistical significance of its structural loads was analyzed. Table 5 and Fig. 3 show the results of the applied structural equation analysis and the results of the research hypotheses.

With regard to relationships, we have to take into account the $p$-value column corresponding to each variable where the associated $p$-value less than 0.05 show significant relationships associated (or quasi-significant 0.05-0.10). In our particular case, all relationships are significant except for those produced between usefulness or risk and intention to use ( $\mathrm{H} 4$ and $\mathrm{H} 12)$.

First, with respect to the effects of perceived ease of use, we found empirical evidence to support the statements of the hypotheses $\mathrm{H} 1$ and $\mathrm{H} 2$. Specifically, the importance of the usefulness variable regarding the adoption of the
Table 4 Goodness-of-fit indicators in the structural model.

\begin{tabular}{lc}
\hline Indicator & Value \\
\hline RMSEA & 0.08 \\
RFI & 0.86 \\
GFI & 0.86 \\
AGFI & 0.87 \\
NFI & 0.88 \\
CFI & 0.95 \\
IFI & 0.95 \\
TLI & 0.94 \\
\hline
\end{tabular}

Notes: RMSEA, root mean square error of approximation; RFI, relative fix index; GFI, goodness-of-fit index; AGFI, adjusted goodness-of-fit index; NFI, normed fit index; CFI, comparative goodness of fit; IFI, incremental fit index; TLI, Tucker-Lewis index.

proposed m-banking app is demonstrated through the attitude toward such app (one $\beta=0.21 ; p=0.058$ ), as it was pointed out in research conducted by Chau and Lai (2003) in e-banking context or Hernández (2010) and Muñoz et al. (2012) for travel 2.0 tools. We can also confirm the positive effect of the ease of use on the usefulness of the proposed app $(\beta=0.61 ; p=0.000)$, as it appeared in researches conducted by Stern, Royne, Stafford, and Bienstock (2008) and Muñoz et al. (2012).

As for the effects of usefulness, empirical evidence is found to accept $\mathrm{H} 3$, demonstrating the relevance of usefulness through the attitude of the proposed mobile app $(\beta=0.46 ; p=0.000)$, as it appeared in research by Wu and Chen (2005) and Muñoz et al. (2012). By contrast, there is no empirical evidence to accept $\mathrm{H} 4(\beta=-0.18 ; p=0.134)$, thus failing to demonstrate the importance of usefulness through the intention to use the m-banking.

Regarding the effects of attitude, empirical evidence is found to accept hypothesis H5. Thus, we can confirm the importance of attitude toward intention to use a mobile application $(\beta=0.88 ; p=0.000)$, as it had been demonstrated in research by Chang and Wu (2012) in the e-commerce context.

Table 5 Non-standardized coefficients $(\beta)$ of the models.

\begin{tabular}{lcccc}
\hline Hypothesis & Estimates & Standard error & $p$-value & Result \\
\hline H1: PEOU $\rightarrow$ ATT & 0.21 & 0.12 & 0.058 & Supported \\
H2: PEOU $\rightarrow$ PU & 0.61 & 0.08 & 0.000 & Supported \\
H3: PU $\rightarrow$ ATT & 0.46 & 0.13 & 0.000 & Supported \\
H4: PU $\rightarrow$ IU & -0.18 & -0.30 & 0.134 & Not supported \\
H5: ATT $\rightarrow$ IU & 0.88 & 1.14 & 0.000 & Supported \\
H6: SI $\rightarrow$ PEOU & 0.21 & 0.05 & 0.007 & Supported \\
H7: SI $\rightarrow$ & 0.24 & 0.04 & 0.003 & Supported \\
H8: SI $\rightarrow$ ATT & 0.19 & 0.05 & 0.006 & Supported \\
H9: TRU $\rightarrow$ PR & -0.67 & -0.77 & 0.000 & Supported \\
H10: TRU $\rightarrow$ PEOU & 0.70 & 0.08 & 0.000 & Supported \\
H11: TRU $\rightarrow$ ATT & 0.22 & 0.09 & 0.027 & Supported \\
H12: PR $\rightarrow$ IU & -0.12 & -0.12 & 0.104 & Not supported \\
\hline
\end{tabular}




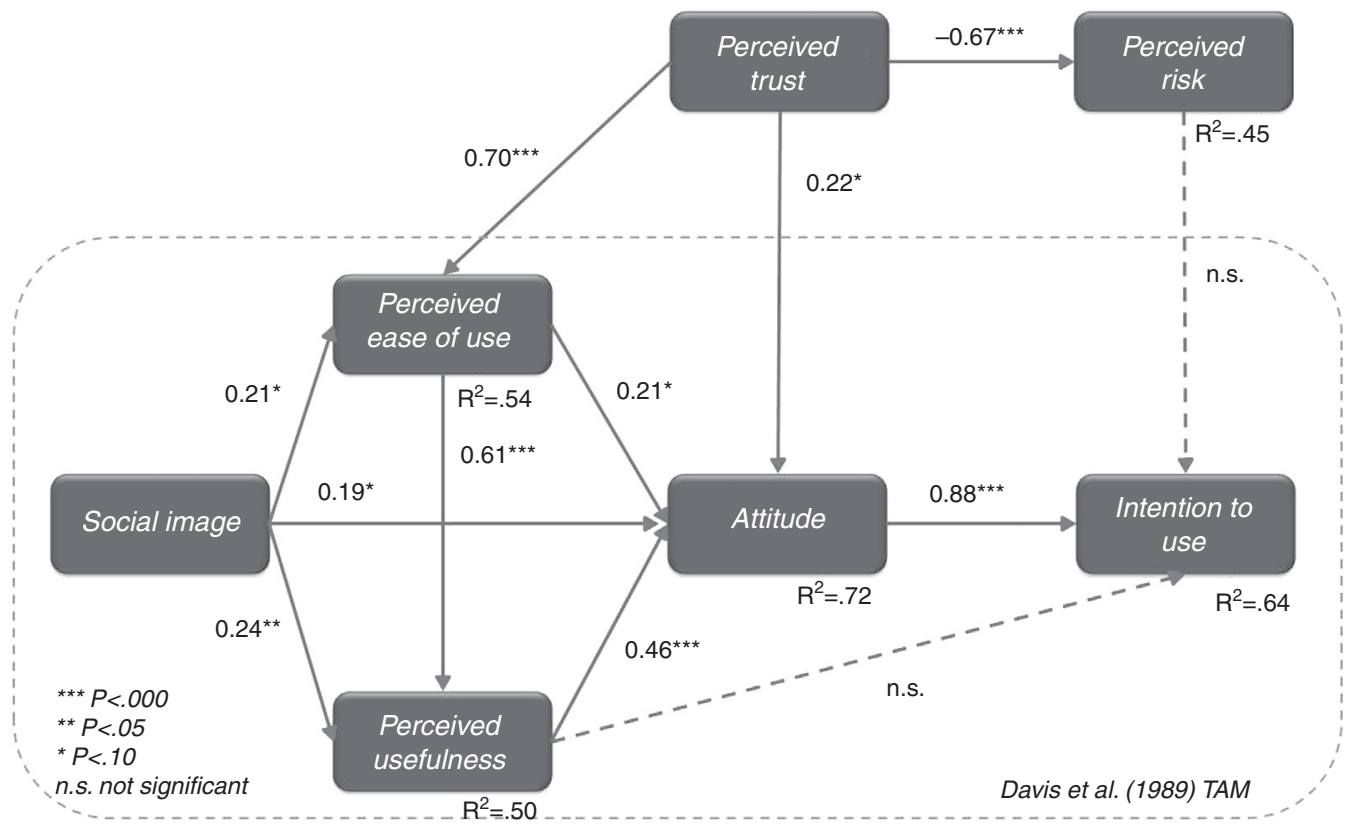

Figure 3 Behavioral model (standardized betas).

Furthermore, there is empirical evidence to accept the referenced hypotheses on the effects of social image (H6-H8).

Also, the importance of social image through the use of the $\mathrm{m}$-banking app proposal $(\beta=0.24, p=0.003)$ is shown, as noted in researches of Rouibah and Abbas (2011) and Zhang, Yue, and Kong (2011). It is also proven the importance of social image on ease of use $(\beta=0.21 ; p=0.007)$, as also demonstrated in research by Lu, Yao, and Yu (2005) and Bhatti (2007). The positive effect of social image on attitude toward the proposed application $(\beta=0.19 ; p=0.006)$ is also confirmed, as stated in previous studies by Taylor and Todd (1995). Moreover, the importance of social image through the usefulness of the proposed mobile application $(\beta=0.24 ; p=0.003)$ is also shown, as previously noted in studies by Rouibah and Abbas (2011) and Zhang et al. (2011).

As for the effects of trust, empirical evidence exists to accept hypotheses $\mathrm{H} 10$ and $\mathrm{H} 11$, thus demonstrating the positive effect on the ease of use of the app $(\beta=0.70$; $p=0.000)$, as shown in research by Pavlou (2002, 2003) and Lin, Shih, and Sher (2007). Also shown is the importance of trust through the attitude $(\beta=0.22 ; p=0.027)$, as confirmed in studies by Oh et al. (2009) and Alsajjan and Dennis (2010). Also, the negative effect of trust on risk - H9 $(\beta=-0.67 ; p=0.000)$ is confirmed, as stated in research by Pavlou (2003) and Silva-Bidarra, Muñoz-Leiva, and LiébanaCabanillas (2013).

Finally, there is not empirical evidence to accept hypothesis $\mathrm{H} 12$, that is, the negative effect of perceived risk on the intention to use the m-banking application happens in the expected direction, as had been noted in research of $\mathrm{Lu}$, Yang, Chau, and Cao (2011), Huang, Tsay, Huan, Li, and Lai (2011) and Chen (2013), but it is not statistically significant $(\beta=-0.12 ; p=0.104)$.

\section{Final discussion, limitations and future research}

\section{Main conclusions.}

The research aim of this article is to study those beliefs and behavioral variables that influence the use of mobile banking applications, as well as providing conclusions beyond mere descriptive analysis. To achieve the aim of this study, we have based on the traditional TAM model, to which relevant variables have been added in the adoption of an innovation such as social image, trust or risk associated with the proposed app. For analysis of the proposed theoretical model, an online survey has been launched.

A total of 12 hypotheses were formulated in order to analyze the relationships between the constructs of the proposed theoretical model. Finally, almost all significant assumptions have been proven empirically and statistically significant.

Thus, research and data analysis make several theoretical and practical contributions. First, and after the analyses were done, we found that the attitude, with the strongest effect, determines predisposition to use m-banking apps, as previous studies found out (e.g. Schierz et al., 2010, in mobile payment services).

We have to highlight the positive effect of ease of use on the usefulness of the proposed app, as obtained in research of Aldás et al. (2011) and Muñoz et al. (2012). They also confirmed that trust has a positive effect on the ease of use of the mobile apps, in line with earlier studies (e.g. Pavlou, 2002, 2003; Bounagui \& Nel, 2009).

The relationship between perceived usefulness and intention to use is not confirmed, only we can state that the relationship is very weak and without explanatory power in this case. Contrary to the principles of the TAM model, 
it has been impossible to demonstrate the positive effect of usefulness on the intention of use of the mobile application. Previous studies reach the same conclusion as in the case of Muñoz-Leiva, Hernández-Méndez, and SánchezFernández (2012), where the display of more complex tools (such as Facebook and Trip Advisor) exerts a greater effect than others that are easier to use, such as a simple blog. Here, an explanation of the lack of effect may be based on the simplicity of the tool and loss of usefulness of these apps when the replacement exists, such as an online version or by Web. These results are also consistent with Jiang, Peng, and Liu (2015); the authors identify usefulness of mobile games as a construct that contribute to improve the life of a person via other aspects as enjoyment or entertainment, which would justify the positive relationship on attitude toward the system.

Even weaker is the relationship between perceived risk and intention of using it. In this respect, this result is in line with recent research applied to different innovations where the user does not consider the risk of using them in the future. In this sense, different studies (e.g. Ruiz Mafé \& Tronch, 2007) rejected the influence of risk in all its dimensions analyzed on the intention to purchase distance courses, or Rouibah, Lowry, and Hwang (2016) in the field of adoption of mobile payments under a crosscultural study comparing the Italian and Chinese population on intentions to seek and share health information on social media. From our point of view, the experience in this type of tools improves the intention of use, being perceived by the user as a technology with a low risk exposure and without being determinant in its adoption (Phang et al., 2006).

However, thanks to mobile devices and the breakthrough of ICT, access to mobile banking applications is a fact, thus changing the channel for interaction and engagement between banks and customers. Owing to the relevance and importance of the subject, the results of the study lead to interesting implications when it comes to the spreading of these mobile applications; understanding the adoption or acceptance of such is also important when defining a strategy to attract new users.

With this aim, it is desirable that banks make communication campaigns explaining the advantages achieved with this type of mobile application, in order to make users see the usefulness of them and increase their intention to use via attitude. The extension introduced into the TAM model could also affect the design of communication campaigns trying to obtain increased trust and mitigate risk and uncertainty, characteristics attributable to the application itself and the people who are responsible for their development, maintenance, protection and control.

\section{Managerial implications}

Banking companies are well aware that smartphones are becoming the favorite personal devices and gadgets of the Spanish population in particular and the same can be said about the worldwide population for the most part. According to a recent KPMG report (2015), by 2019 it is expected that more than 1800 million of users will be interacting with their banking companies through smartphone apps. Regarding this trend, Spain is leading the EU ambit respecting the use of smartphones and other mobile devices to approach financial operations. This new relationship between the user and the financial entity makes the latter feel obliged to analyze and define users' behavior within this new technological context.

Our study allows different implications for the companies that make up the ecosystem in the banking management of the users. As we have seen, the attitude has a significant, positive and direct effect on the intention to use derived from the usefulness of the analyzed m-banking app, perceived ease of use and social image. This favorable attitude toward the use of the mobile application is the only determinant of the intention, since it has not found significance in the effect of risk and usefulness on it. In this regard, user attitudes will reflect people's favorable or unfavorable feelings toward a behavior, which implies that attitudes will develop over time as people gain experience. Therefore, financial institutions should promote in a sustained manner the value of this type of services based on: a) the main attributes of mobile banking (Prodanova, San-Martín, \& Jiménez, 2015) and b) on future functional and psychosocial benefits (Frambach, Roest, \& Krishnan, 2007); such as the development of new services in the apps, the improvement of information and the integration of new social trends (social commerce, Facebook commerce, etc.).

In addition it would be interesting that the apps allow the customization based on user profile and on its requirements, and focusing the effort in actions of CRM (Customer Relationship Management) and cross selling.

On the other hand, we highlight the fact that, in our study both perceived risk and perceived usefulness, do not achieve a significant effect on intention. They are variables that lose their importance due to the experience effect already commented. Those users with experience in mobile apps (banking or not) will reduce their aversion to risk associated with their implementation, improving their perception of usefulness and encouraging their use on a continuous basis over time (O'cass \& Fenech, 2003). In a similar sense, it is confirmed that the adoption of mobile services (Ristola, 2010 ) is conditioned by previous users experience, improving their intention to use (Niemelä-Nyrhinen, 2007).

Despite this, some drivers and barriers analyzed in this research (such as trust, risk or the social image) along with other variables that this research did not approach (such as the level of innovation or the perceived compatibility) will determine users' adoption and use of this type of mobile applications.

In the near future, m-banking apps will be influenced by significant agreements and relationships that financial entities are nowadays developing. One major factor to be taken into account is Bizum, an instant payment system (it takes $10 \mathrm{~s}$ or less to complete a transaction) involving users' own mobile devices; it is expected that, by the last term in 2016, this system will replace a great percentage regarding traditional transfers (which involve 24 digits and would take up to 48 hours to complete). Bank companies will be offering their customers the possibility to connect their mobile telephone number with their bank accounts in order to enable transfers to contacts available in their mobile device. This technology would of course run in accordance of a significant set of security requirements and protocols. 


\section{Limitations and future lines of research}

This article presents a series of limitations that should be debated and that generate new lines of research for the future. Firstly, limitations were found in the selected sample; participating users in the sample limited the interaction with the tool to the viewing of a video, through which they then answered questions in a survey. In this sense, our research has focused on the measurement of an intention, not on measuring actual behavior. Consequently, our work could be extended in the future with real experience with use of the real tool, making pertinent comparisons between intention and behavior, assessing the possible prior expectations of users and the effects on them once the user has actually interacted with the mobile application.

Furthermore, methodological limitations were also found when conducting research, since the total sample was fairly small. In this regard, we have to remain cautious when generalizing the results of this research since it uses a small-sized sample In order to overcome this limitation, the sample should be extended and/or approaching other modeling tools based on covariance which are more appropriate for samples of this size, such as the partial least square (PLS) modeling technique. Therefore, in future studies, it would be advisable to try to improve the representativeness and thus, the greatest potential for generalization of results from a larger sample nationwide.

Additionally, data collection was carried out using a crosssectional; future research could be improved by using a longitudinal technique so as to allow us to assess the evolution of the predisposition/loyalty after the actual usage.

Future lines of research should study, with the highest possible diligence, other variables that influence on consumer behavior regarding m-banking apps (compatibility with style of using banking services, involvement with new technologies, experience with these tools, etc.), owing to the need, timeliness and originality of the subject.

Also, for future studies, it would be interesting to consider classification variables and then analyze the moderating effect of these characteristics. Variables related to gender, age, social status, experience or user involvement with mobile applications of banks would be good examples, as well as the influence of the type of device, differentiating between smartphones and tablets, among others.

Another possible line of research would be to conduct cross-cultural studies that attempt to validate the model in other countries, taking into account the socio-demographic characteristic traits and cultural differences of different countries of origin of the respondents.

\section{Conflict of interest}

None declared.

\section{Acknowledgement}

This study has been conducted with financial support received from Excellence Research Project P12-SEJ-1980 of the Andalusia Regional Government and Project ECO201239576 of Spanish Ministry of Economy and Competitiveness.

\section{Appendix A.}

Table 4 Questionnaire and name of measurement scales ${ }^{\mathrm{a}}$ (ID).

\section{Social image}

The people around me who use this type of apps have more prestige than those who do not use them (SI1)

The people around me who use these apps have a higher status (SI2)

Using such apps is a status symbol in my environment (SI3)

Perceived ease of use

The interaction with Banco Santander's mobile application is clear and understandable (PEOU1)

Interaction with the app requires mental effort (PEOU2)

I find the app easy to use for whatever I want to do (PEOU3)

The tool is easy to use in general (PEOU4)

Perceived usefulness

Using Banco Santander's mobile application can help consult and/or conduct my banking transactions (PU1)

Using the mobile application of Banco Santander increased my effectiveness in consulting and/or conducting my banking transactions (PU2)

In general, the mobile application Santander Bank can be useful when consulting and/or conducting my banking transactions (PU3)

Attitude

Use the mobile application of Banco Santander for queries and/or making my banking is an idea that (ATT1)

Us the mobile application of Banco Santander for queries and/or making my banking is an idea (ATT2)

Use the mobile application of Banco Santander for queries and/or doing my banking is an idea (ATT 3)

Intention to use

Assuming you have access to the mobile application of Banco Santander, you would intend to use it (IU1)

If I had access to the mobile app Banco Santander over the coming months, I believe that I will use it instead of other systems (IU2)

Perceived trust

I think that Banco Santander will maintain the terms and commitments made in relation to the mobile app (TRU1)

I think that Banco Santander's mobile app is reliable (TRU2)

In general, I trust Banco Santander's mobile app (TRU3)

Perceived risk

Others may know information about my online transactions if I use this app (PR1)

There is a significant risk when making my queries and/or my banking transactions through the mobile app Banco Santander (PR2)

I believe that making queries and/or banking transactions with this app is a risky choice (PR3)

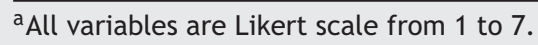

\section{References}

Aboelmaged, M., \& Gebba, T. R. (2013). Mobile banking adoption: An examination of technology acceptance model and theory of 
planned behavior. International Journal of Business Research and Development (IJBRD), 2(1), 719-729.

Agag, G., \& El-Masry, A. A. (2016). Understanding the determinants of hotel booking intentions and moderating role of habit. International Journal of Hospitality Management, 54, 52-67.

Ajzen, I., \& Fishbein, M. (1980). Understanding attitudes and predicting social behavior. London: Prentice Hall International.

Alcántara, J. M. (2012). Modelización del comportamiento del consumidor online. El papel moderador de la cultura, el diseño web y el idioma. Tesis. Departamento de Comercialización e Investigación de Mercados, Universidad de Granada.

Aldás, J., Lassala, C., Ruiz, C., \& Sanz, S. (2011). Análisis de los factores determinantes de la lealtad hacia los servicios bancarios. Cuadernos de Economía y Dirección de la Empresa, 14, 26-39.

Alsajjan, B., \& Dennis, C. (2010). Internet banking acceptance model: Cross-market examination. Journal of Business Research, 63(9), 957-963.

Anderson, J. C., \& Gerbing, D. W. (1988). Structural equation modeling in practice: A review and recommended two-step approach. Psychological Bulletin, 103(3), 411-423.

Bao, Y., Zhou, K. Z., \& Su, C. (2003). Face consciousness and risk aversion: Do they affect consumer decision-making. Psychology and Marketing, 20(8), 733-755.

Bauer, R. A. (1960). Consumer behavior as risk-taking. In R. S. Hancock (Ed.), Dynamic marketing for a changing world (pp. 389-398). Chicago: American Marketing Association. Cited from D. F. Cox (Ed.), Risk-taking and information-handling in consumer behavior. Boston: Harvard University Press, 1967, pp. 23-33.

Bauer, R. A. (1967). Consumer behavior as risk taking. In D. F. Cox (Ed.), Risk-taking and information-handling in consumer behavior (pp. 23-33). Boston: Harvard University Press.

Bhatti, T. (2007). Exploring factors influencing the adoption of mobile commerce. Journal of Internet Banking and Commerce, 12(3), 1-13.

Bollen, K. A. (1990). Overall fit in covariance structure models: Two types of sample size effects. Psychological Bulletin, 107(2), 256.

Bashir, I., \& Madhavaiah, C. (2015). Trust, social influence, selfefficacy, perceived risk and internet banking acceptance: An extension of technology acceptance model in indian context. Metamorphosis: A Journal of Management Research, 14(1), 25-38.

Bounagui, M., \& Nel, J. (2009). Towards understanding intention to purchase online music downloads, Management Dynamics. Journal of the Southern African Institute for Management Scientists, 18(1), 15-26.

Chang, M. L., \& Wu, W. Y. (2012). Revisiting perceived risk in the context of online shopping: An alternative perspective of decision-making styles. Psychology \& Marketing, 29(5), 378-400.

Chau, P. Y. K. , \& Lai, V. S. K. (2003). An empirical investigation of the determinants of user acceptance of internet banking. Journal of Organizational Computing and Electronic Commerce, 13(2), 123-145.

Chauhan, S. (2015). Acceptance of mobile money by poor citizens of India: Integrating trust into the technology acceptance model. Info, 17(3), 58-68.

Chen, C. (2013). Perceived risk, usage frequency of mobile banking services. Managing Service Quality, 23(5), 410-436.

Chong, A. Y. L., Ooi, K. B., Lin, B., \& Bao, H. J. (2012). An empirical analysis of the determinants of $3 \mathrm{G}$ adoption in China. Computers in Human Behavior, 28, 360-369.

Crespo, A. H., \& del Bosque, I. R. (2010). The influence of the commercial features of the Internet on the adoption of ecommerce by consumers. Electronic Commerce Research and Applications, 9(6), 562-575.

Davis, F. D. (1989). Perceived usefulness, perceived ease of use, and user acceptance of information technology. MIS Quarterly, 13(3), 319-340.
Davis, F. D., Bagozzi, R. P., \& Warshaw, P. R. (1989). User acceptance of computer technology: A comparison of two theoretical models. Management Science, 35, 982-1003.

Del Barrio, S., \& Luque, T. (2012). Análisis de Ecuaciones Estructurales In Luque, T. (coord.), Técnicas de Análisis de datos en investigación de mercados. Barcelona: Pirámide.

Dwyer, F. R., Schurr, P. H., \& Oh, S. (1987). Developing buyer-seller relationship. Journal of Marketing, 51(2), 11-27.

Featherman, M. S., \& Pavlou, P. A. (2003). Predicting e-services adoption: A perceived risk facets perspective. International Journal of Human-Computer Studies, 59, 451-474.

Finney, S. J., \& DiStefano, C. (1996). Nonnormal and categorical data in structural equation modeling. In G. R. Hancock, \& R. O. Mueller (Eds.), Structural equations modeling: A second course. Greenwich, Connecticut, USA: Information Age Publishing Inc.

Fishbein, M., \& Ajzen, I. (1975). Belief, attitude, intention and behavior: An introduction to theory and research. Reading, MA: Addison-Wesley.

Flavián, C., Guinalíu, M., \& Gurrea, R. (2004). Análisis empírico de la influencia ejercida por la usabilidad percibida, la satisfacción y la confianza sobre la lealtad de un sitio web XVI Encuentros de Profesores Universitarios de Marketing. pp. 209-226. Madrid: ESIC.

Fornell, C., \& Larcker, D. F. (1981). Evaluating structural equation models with unobservable variables and measurement error. Journal of Marketing Research, 18(1), 39-50.

Frambach, R. T., Roest, H. C., \& Krishnan, T. V. (2007). The impact of consumer internet experience on channel preference and usage intentions across the different stages of the buying process. Journal of interactive marketing, 21(2), 26-41.

Gefen, D., Rao, V., \& Tractinsky, N. (2003). Conceptualization of trust, risk and their relationship in electronic commerce: The need for clarifications. In Proceedings of the 36th Hawaii international conference on IS.

Gefen, D., Karahanna, E., \& Straub, D. W. (2003). Inexperience and experience with online Stores: The importance of TAM and Trust. IEE Transactions on Engineering Management, 50(3, agosto), 307-321.

Gerrard, P., \& Cunningham, J. (2003). The diffusion of internet banking among Singapore consumers. International Journal of Bank Marketing, 21(1), 16-28.

Goffman, E. (1967). Interaction ritual. New York: Pantheon.

Grandón, E. E., Nasco, S. A., \& Mykytyn, P. P. (2011). Comparing theories to explain e-commerce adoption. Journal of Business Research, 64(3), 292-298.

Gu, J. C., Lee, S. C., \& Suh, Y. H. (2009). Determinants of behavioral intention to mobile banking. Expert Systems with Applications, 36(9), 11605-11616.

Gupta, S., \& Kim, H. W. (2010). Value-driven Internet shopping: The mental accounting theory perspective. Psychology \& Marketing, 27(1), 13-35.

Ha, I., Yoon, Y., \& Choi, M. (2007). Determinants of adoption of mobile games under mobile broadband wireless access environment. Information \& Management, 44(3), 276-286.

Hair, J. F., Anderson, R. E., Tatham, R. L., \& William, C. B. (1995). Multivariate data analysis with readings. New Jersey: PrenticeHall, Inc.

Harris, M. A., Brookshire, R., \& Chin, A. G. (2016). Identifying factors influencing consumers' intent to install mobile applications. International Journal of Information Management, 36(3), 441-450.

Harrison, D. (2015). Mobile banking acceptance among young consumers in Germany: An empirical analysis (Doctoral dissertation, BI Norwegian Business School).

Hernández, J. (2010). Análisis y modelización del comportamiento de uso de las herramientas Travel 2.0. Departamento de Comercialización e Investigación de Mercados, Universidad de Granada. 
Herrero, A., \& San Martín, H. (2012). Effects of the risk sources and user involvement on e-commerce adoption: Application to tourist services. Journal of Risk Research, 15(7), 841-855.

Hew, J. J., Lee, V. H., Ooi, K. B., \& Wei, J. (2015). What catalyses mobile apps usage intention: An empirical analysis. Industrial Management \& Data Systems, 115(7), 1269-1291.

Hong, S. J., \& Tam, K. Y. (2006). Understanding the adoption of multipurpose information appliances: The case of mobile data services. Information Systems Research, 17(2), 162-179.

Hsu, C. L., \& Lin, J. C. C. (2016). Effect of perceived value and social influences on mobile app stickiness and in-app purchase intention. Technological Forecasting and Social Change, 108, 42-53.

Hsu, C. L., \& Lu, H. P. (2007). Consumer behavior in online game communities: A motivational factor perspective. Computers in Human Behavior, 23(3), 1642-1659.

Huang, Y. C., Tsay, W. D., Huan, C. H., Li, Y. H., \& Lai, M. C. (2011). The influence factors of electronic bill presentment and payment. In case study of mobile phone bill. IEEE, 4844-4847.

ING. (2013). Encuesta Internacional sobre el Empoderamiento Financiero en la Era Digital de ING.. Retrieved from http://www. ingdirect.es/sobre-ing/prensa/prensa250713.html

Jeong, B. K., \& Yoon, T. E. (2013). An empirical investigation on consumer acceptance of mobile banking services. Business and Management Research, 2(1), 31.

Jiang, G., Peng, L., \& Liu, R. (2015). Mobile game adoption in China: The role of TAM and perceived entertainment, cost, similarity and brand trust. International Journal of Hybrid Information Technology, 8(4), 213-232.

Ko, E., Kim, E. Y., \& Lee, E. K. (2009). Modeling consumer adoption of mobile shopping for fashion products in Korea. Psychology \& Marketing, 26(7), 669-687.

KPMG. (2015). Informe Global de Banca Móvil.. Retrieved from http://www.kpmg.com/ar/es/prensa/gacetillasdeprensa/ paginas/informe-global-de-banca-movil-realizado-por-kpmg. aspx

Krishanan, D., Khin, A. A., Teng, K. L. L., \& Chinna, K. (2016). Consumers' perceived interactivity \& intention to use mobile banking in structural equation modeling. International Review of Management and Marketing, 6(4), 883-890.

Kulviwat, S., Bruner, I. I., Gordon, C., Kumar, A., Nasco, S. A., \& Clark, T. (2007). Toward a unified theory of consumer acceptance technology. Psychology\& Marketing, 24(12), 1059-1084.

Lai, J. Y., \& Li, D. H. (2005). Technology acceptance model for internet banking: An invariante analysis. Information \& Management, 42, 373-386.

Laukkanen, T. (2007). Internet vs mobile banking: Comparing customer value perceptions. Business Process Management Journal, 13(6), 788-797.

Lee, M., McGoldrick, P. J., Keeling, K. A., \& Doherty, J. (2003). Using ZMET to explore barriers to the adoption of $3 \mathrm{G}$ mobile banking services. International Journal of Retail and Distribution Management, 31, 340-348.

Li, H., Liu, Y., \& Heikkilä, J. (2014). Understanding the factors driving NFC-enabled mobile payment adoption: An empirical investigation. PACIS, 231.

Liang, C. C. (2016). Subjective norms and customer adoption of mobile banking: Taiwan and Vietnam. In 2016 49th Hawaii international conference on system sciences (HICSS). pp. 1577-1585. IEEE.

Liébana Cabanillas, F. J. (2012). El papel de los sistemas de pago en lo nuevos entornos electrónicos. Granada: Universidad de Granada.

Liébana-Cabanillas, F., Muñoz-Leiva, F., \& Sánchez-Fernández, J. (2017). A global approach to the analysis of user behavior in mobile payment systems in the new electronic environment. Service Business (in press).
Liébana-Cabanillas, F., Muñoz-Leiva, F., \& Rejón-Guardia, F. (2013). The determinants of satisfaction with e-banking. Industrial Management \& Data Systems, 113(5), 750-767.

Liébana-Cabanillas, F., Sánchez-Fernández, J., \& Muñoz-Leiva, F. (2014a). Antecedents of the adoption of the new mobile payment systems: The moderating effect of age. Computers in Human Behaviour, 464-478.

Liébana-Cabanillas, F., Sánchez-Fernández, J., \& Muñoz-Leiva, F. (2014b). The moderating effect of experience in the adoption of mobile payment tools in Virtual Social Networks: The m-Payment Acceptance Model in Virtual Social Networks. International Journal of Information Management, 151-166.

Lin, C. H., Shih, H. Y., \& Sher, P. J. (2007). Integrating technology readiness into technology acceptance: The TRAM model. Psychology \& Marketing, 24(7), 641-657.

Lin, C. P., \& Bhattacherjee, A. (2010). Extending technology usage models to interactive hedonic technologies: A theoretical model and empirical test. Information Systems Journal, 20(2), 163-181.

Liu, Y., \& Li, H. (2011). Exploring the impact of use context on mobile hedonic services adoption: An empirical study on mobile gaming in China. Computers in Human Behavior, 27(2), 890-898.

López-Nicolás, C., Molina-Castillo, F. J., \& Bouwman, H. (2008). An assessment of advanced mobile services acceptance: Contributions from TAM and diffusion theory models. Information \& Management, 45, 359-364.

Lu, J., Yao, J., \& Yu, C. (2005). Personal innovativeness, social influences and adoption of wireless Internet services via mobile technology. The Journal of Strategic Information Systems, 14(3), 245-268.

Lu, Y., Yang, S., Chau, P., \& Cao, Y. (2011). Dynamics between the trust transfer process and intention to use mobile payment services: A cross-environment perspective. Information \& Management, 48, 393-403.

Luo, X., Li, H., Zhang, J., \& Shim, J. P. (2010). Examining multidimensional trust and multi-faceted risk in initial acceptance of emerging technologies: An empirical study of mobile banking services. Decision Support Systems, 49(2), 222-234.

Luque, T. (1997). Investigación de marketing. Fundamentos. Barcelona: Ariel.

Malhotra, N. K. (1997). Investigación de Mercados. Un enfoque práctico 2a Ed. México: Prentice Hall Hispanoamericana.

Moore, G. C., \& Benbasat, I. (1991). Development of an instrument to measure the perceptions of adopting an information technology innovation. Information Systems Research, 2(3), 192-222.

Muñoz, F. (2008). La adopción de una innovación basada en la Web Tesis Doctoral. Departamento de Comercialización e Investigación de Mercados, Universidad de Granada.

Muñoz-Leiva, F., Hernández-Méndez, J., \& Sánchez-Fernández, J. (2012). Generalising user behaviour in online travel sites through the Travel 2.0 website acceptance model. Online Information Review, 36(6), 879-902.

Muñoz-Leiva, F., Sánchez-Fernández, J., \& Luque-Martínez, T. (2010). How to improve trust toward electronic banking. Online Information Review, 34(6), 907-934.

Niemelä-Nyrhinen, J. (2007). Baby boom consumers and technology: Shooting down stereotypes. Journal of Consumer Marketing, 24(5), 305-312.

Nunnally, J. C. (1978). Psycometric theory (2nd ed.). New York: McGraw-Hill.

O'cass, A., \& Fenech, T. (2003). Web retailing adoption: Exploring the nature of internet users Web retailing behaviour. Journal of Retailing and Consumer Services, 10(2), 81-94.

Oh, S. H., Kim, Y. M., Lee, C. W., Shim, G. Y., Park, M. S., \& Jung, H. S. (2009). Consumer adoption of virtual stores in Korea: Focusing on the role of trust and playfulness. Psychology \& Marketing, 26(7), 652-668. 
Park, E., Baek, S., Ohm, J., \& Chang, H. J. (2014). Determinants of player acceptance of mobile social network games: An application of extended technology acceptance model. Telematics and Informatics, 31(1), 3-15.

Park, S., \& Tussyadiah, I. P. (2016). Multidimensional facets of perceived risk in mobile travel booking. Journal of Travel Research, http://dx.doi.org/10.1177/0047287516675062. First Online Published, October 27, 2016. Available in: $\quad$ http://journals.sagepub.com/doi/abs/10.1177/0047 287516675062

Pavlou, P. A. (2002). A theory of planned behavior perspective to the consumer adoption of electronic commerce. MIS Quarterly, 30(1), 115-143.

Pavlou, P. A. (2003). Consumer acceptance of electronic commerce: Integrating trust and risk with the technology acceptance model. International Journal Electronic Commerce, 7(3), 69-103.

Pham, T. T. T., \& Ho, J. C. (2015). The effects of product-related, personal-related factors and attractiveness of alternatives on consumer adoption of NFC-based mobile payments. Technology in Society, 43, 159-172.

Phang, C. W., Sutanto, J., Kankanhalli, A., Li, Y., Tan, B. C., \& Teo, H. H. (2006). Senior citizens' acceptance of information systems: A study in the context of e-government services. IEEE Transactions on Engineering Management, 53(4), 555-569.

Price Waterhouse Coopers. (2013). Global insights and actions for Banks in the digital age.. Retrieved from http://www.pwc.es/es/publicaciones/financiero-seguros/ encuesta-mundial-banca-digital.jhtml

Prodanova, J., San-Martín, S., \& Jiménez, N. (2015). El presente y el futuro de la banca por móvil según los usuarios españoles de banca. Universia Business Review, 46, 94-117.

Reichheld, F. F., \& Schefter, P. (2000). E-loyalty: Your secret weapon on the web. Harvard Business Review, 78(4), 105-113.

Rifon, N. J., LaRose, R. , \& Choi, S. M. (2005). Your privacy is sealed: Effects of web privacy seals on trust and personal disclosures. The Journal of Consumer Affairs, 39(2), 339-362.

Ristola, A. (2010). Insights into customers emerging interest in mobile services. Department of Marketing: University of Oulu.

Rogers, E. M. (2003). Diffusion of innovations (5th ed.). New York, NY: Free Press.

Rouibah, K., \& Abbas, H. (2011). Effect of personal innovativeness, attachement motivation and social norms on the acceptance of camera mobile phones: An empirial study in an Arab Country. International Journal of Handheld Computing Research, 1(4), 41-62.

Rouibah, K., Lowry, P. B., \& Hwang, Y. (2016). The effects of perceived enjoyment and perceived risks on trust formation and intentions to use online payment systems: New perspectives from an Arab country. Electronic Commerce Research and Applications, 19, 33-43.

Ruiz Mafé, C., \& Tronch García de los Ríos, J. E. (2007). Factores determinantes de la decisión de compra en Internet: un análisis de la formación a distancia. Estudios sobre Consumo, 2007, 80, 49-60.

Saghafi, F., Moghaddam, E. N., \& Aslani, A. (2016). Examining effective factors in initial acceptance of high-tech localized technologies: Xamin Iranian localized operating system. Technological Forecasting and Social Change, http://dx.doi.org/10.1016/j.techfore.2016.04.010. Online Publication, 1-May-2016

Schierz, P. G., Schilke, O., \& Wirtz, B. W. (2010). Understanding consumer acceptance of mobile payment services: An empirical analysis. Electronic Commerce Research and Applications, 9(3), 209-216.

Schurr, P. H., \& Ozanne, J. L. (1985, March). Influences on exchange processes: Buyers' preconceptions of a seller's trustworthiness and bargaining toughness. Journal of Consumer Research, 11, 939-953.

Sellitto, C. (2015). User intentions to adopt mobile payment services: A study of early adopters in Thailand. Journal of Internet Banking and Commerce, 20(1), 1-29.

Slade, E. L., Dwivedi, Y. K., Piercy, N. C., \& Williams, M. D. (2015). Modeling consumers' adoption intentions of remote mobile payments in the United Kingdom: Extending UTAUT with innovativeness, risk, and trust. Psychology \& Marketing, 32(8), 860-873.

Shaikh, A. A., \& Karjaluoto, H. (2015, February). Mobile banking adoption: A literature review. Telematics and Informatics, 32(1), 129-142.

Silva-Bidarra, S. H., Muñoz-Leiva, F. \& Liébana-Cabanillas, F. (2013, April-June). Analysis and modeling of the determinants of mobile banking acceptance. The International Journal of Management Science and Information Technology (IJMSIT), 1-27.

Stern, B. B., Royne, M. B., Stafford, T. F., \& Bienstock, C. C. (2008). Consumer acceptance of online auctions: An extension and revision of the TAM. Psychology \& Marketing, 25(7), 619-636.

Stewart, K. (2003). Trust transfer on the World Wide Web. Organization Science, 14(1), 5-17.

Taylor, S., \& Todd, P. (1995). Understanding information technology usage: A test of competing models. Information Systems Research, 6(2), 144-176.

Tecnocom Report. (2012). Tendencias en Medios de Pago 2012.. Retrieved from http://www.afi.es/afi/libre/PDFS/Grupo/ Documentos/Informe_Tecnocom12.pdf

Venkatesh, V., \& Bala, H. (2008). Technology acceptance model 3 and a research agenda on interventions. Decision Sciences, 39(2), 273-315.

Venkatesh, V., \& Davis, F. D. (2000). A theoretical extension of the technology acceptance model: Four longitudinal field studies. Management Science, 46(2), 186-204.

West, S. G., Finch, J. F., \& Curran, P. J. (1995). Structural equations models with nonnormal variables: Problems and remedies. In R. H. Hoyle (Ed.), Structural equation model: Concepts, issues, and applications (pp. 57-75). Newbury Park, CA: Sage Publications.

White, J. B., Tynan, R., Galinsky, A. D., \& Thompson, L. (2004). Face threat sensitivity in negotiation: Roadblock to agreement and joint gain. Organizational Behavior and Human Decision Processes, 94(2), 102-124.

Wu, I. L., \& Chen, J. L. (2005). An extension of Trust and TAM model with TPB in the initial adoption of on-line tax: An empirical study. International Journal of Human-Computer Studies, 62, 784-808.

Youtube. (2012). Nueva aplicación de Banco Santander para Iphone - Demo.. Retrieved from https://www.youtube. $\mathrm{com} /$ watch? $\mathrm{v}=\mathrm{QXv} 45$ _cCNIE

Zhang, A., Yue, X., \& Kong, Y. (2011). Exploring culture factors affecting the adoption of mobile payment. In 10th international conference on mobile business (pp. 263-267).

Zhang, J., \& Mao, E. (2008). Understanding the acceptance of mobile SMS advertising among young Chinese consumers. Psychology \& Marketing, 25(8), 787-805.

Zhou, T., Lu, Y., \& Wang, B. (2010). Integrating TTF and UTAUT to explain mobile banking user adoption. Computers in Human Behavior, 26(4), 760-767. 